\title{
Burial depths favor Italian ryegrass persistence in the soil seed bank
}

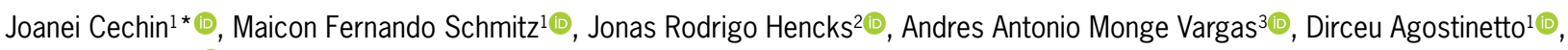 \\ Leandro Vargas ${ }^{4}$ (i)
}

1Universidade Federal de Pelotas - Depto. de Fitossanidade, Av. Eliseu Maciel, s/n - 96010-900 - Capão do Leão, RS Brasil.

2Universidade Estadual de Maringá - Depto. de Agronomia, Av. Colombo, 5790 - 87020-900 - Maringá, PR - Brasil. 3Universidad de Costa Rica/Centro para Investigaciones en Granos y Semillas, Ciudad Universitaria Rodrigo Facio, Calle Costa Rica - 2060 - San José - Costa Rica.

4Embrapa Trigo - Setor de Plantas Daninhas, Rod. BR 285, km 174 - 99001-970 - Passo Fundo, RS - Brasil.

*Corresponding author <joaneicechin@yahoo.com.br>

Edited by: Lincoln Zotarelli

Received March 26, 2019

Accepted October 23, 2019
ABSTRACT: Italian ryegrass (Lolium multiflorum Lam.) is a weed broadly found in fields cultivated with wheat and barley crops. Seed inputs into the soil before harvesting winter crops increase seed bank, ensuring survival. This study evaluated the persistence of Italian ryegrass seeds subjected to burial depths over time. Experiments were carried out in the field for two years in randomized block experimental design with four repetitions. Dormant seeds harvested from mother-plants were put in nylon bags containing soil. Previously, seed viability was evaluated in a $1 \%$ tetrazolium solution, and 50 viable seeds by repetition were buried at $0.5,5.0,10$, and 20 $\mathrm{cm}$ depths. Seed persistence was evaluated by the percentage of deteriorated and remaining seeds, non-dormant seeds, abnormal seedlings, and viable and non-viable dormant seeds at 0 , $30,60,90,180,360,540$, and 720 days after burial (DAB). Seed persistence increased at 10 and $20 \mathrm{~cm}$ of burial depth compared to seeds in the soil layers up to $5 \mathrm{~cm}$. Moreover, burial depth at 10 and $20 \mathrm{~cm}$ showed lower percentage of deteriorated seeds ( $10 \%$ lower) compared to $0.5 \mathrm{~cm}$ at $360 \mathrm{DAB}$. For non-dormant seeds, a higher percentage was found at $90 \mathrm{DAB}$, regardless of seed burial depth. Dormancy breakage occurred until $180 \mathrm{DAB}$, and more rapidly at 10 and $20 \mathrm{~cm}$ depths. At $540 \mathrm{DAB}$, more than $95 \%$ of seeds were unviable, demonstrating short persistence of Italian ryegrass in the soil seed bank.

Keywords: Lolium multiflorum Lam., seed bank weed management, seed longevity, seed dormancy, soil seed bank inputs

\section{Introduction}

Weeds are a major problem for agricultural production, causing significant yield reduction and economic losses worldwide. Italian ryegrass (Lolium multiflorum Lam.) is a winter annual grass species widely found in cropping systems, and considered the most important weed in wheat and barley fields (Vargas and Roman, 2005). Populational infestations have been increasing over the last years due to herbicide resistance, high seed production, premature dehiscence, seed dormancy, and absence of soil disturbance that contributes to seed bank feedback in the soil, providing survival in growing areas and enabling future infestations (Norris, 2007; Fernández-Moreno et al., 2017).

In addition, weed presence and interference capacity in growing areas depends on seed bank and dormancy degree, important factors capable of modifying the emergence moment and crop-weed competition (Ghersa et al., 1997). Seed dormancy in weeds is an evolutionary feature that causes germination delay over time and prevents the establishment under inadequate conditions, allowing population fluctuations (Graeber et al., 2012; Née et al., 2017).

In cropping systems, soil seed bank represents a potential target for management where temporary changes in environmental conditions and soil practices could affect weed population dynamic and exhausting the soil seed bank (Shaner and Beckie, 2014; Armengot et al., 2017). For example, mechanical control during the harvest of grain crops with the Harrington Seed Destructor Machine (HSD) could destroy more than
$95 \%$ of the annual ryegrass (Lolium rigidum Gaudin.) seeds, reducing seed inputs into the soil, essential to reduce weed population sustainably in the long-term in Australian fields (Walsh et al., 2012).

Persistence of viable seeds in soil seed bank without seed destruction depends on biotic and abiotic factors, such as germination cues, seed size and dormancy, predation, and microbial decay, which could be affected by environmental conditions as burial depth and persistence time (Korres et al., 2018). Some management practices, such as plowing and harrowing, cause temporary changes in temperature and water contents in the soil profile, altering the seed dormancy level and viability (Harker and O'Donovan, 2013; He et al., 2014). Conversely, viability of weed seed was higher after burial than in seeds on the soil surface (Sosnoskie et al., 2013; Jha et al., 2014).

Studies conducted for long periods to assess the effects of burial depth and time on viability of Italian ryegrass seeds are important to estimate seed bank persistence and develop weed management strategies. Therefore, this study evaluated persistence of Italian ryegrass seeds at burial depths over time.

\section{Material and Methods}

We evaluated Italian ryegrass seed persistence in a field experiment $\left(31^{\circ} 80^{\prime} 08^{\prime \prime} \mathrm{S}, 52^{\circ} 50^{\prime} 13^{\prime \prime} \mathrm{W}\right.$, altitude of $14 \mathrm{~m}$ ) carried out from Oct 2016 to Oct 2018, using a randomized block experimental design with four repetitions. Previously, \pm 20.000 dormant seeds with viability of $96 \%$ were sampled directly from mother- 
plants and sorted using a diaphanoscope of light. Seed viability was evaluated on 400 seeds, using a $1 \%$ tetrazolium solution kept in the dark at $30{ }^{\circ} \mathrm{C}$ for $6 \mathrm{~h}$, to develop the embryo red color in viable seeds. (MAPA, 2009). Fifty viable seeds were put in naylon bags of 10 $\times 10 \mathrm{~cm}$ with 500-micron pore openings, containing 50 $\mathrm{g}$ of soil, and buried in the field at different depths. The soil was classified as Endoaquult (USDA Soil Taxonomy), with 5.6 of pH, $1.5 \%$ organic matter and $16 \%$ clay. The meteorological conditions during the experiment are shown in Figure 1.

Seed viability of Italian ryegrass was evaluated at four burial depths $(0.5,5.0,10$, and $20 \mathrm{~cm})$, and seeds were recovered at $0,30,60,90,120,360,540$, and 720 DAB (Figure 2). Field samples collected in each time were washed in running water using a set of 16,32 , and 60 mesh sieves. After washing, the samples were placed on filter paper for $24 \mathrm{~h}$, and remaining seeds were

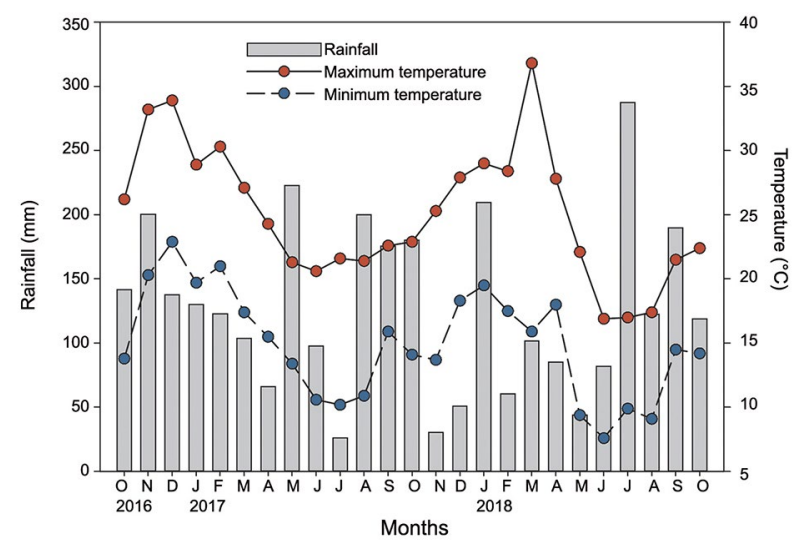

Figure 1 - Meteorological conditions (rainfall, maximum, and minimum temperature) during the experiment on persistence of Italian ryegrass in soil seed bank. collected manually and separated for the germination test. This study was performed at the seed laboratory using germination boxes $(11.5 \times 11.5 \times 3.5 \mathrm{~cm})$, where seeds were distributed over two sheets of blotter paper, previously moistened with distilled water at an amount equivalent to 2.5 -fold the paper weight. The germination test was carried out in a chamber of biochemical oxygen demand (BOD) for $14 \mathrm{~d}$ under alternating temperature $\left(20{ }^{\circ} \mathrm{C}\right.$ for $16 \mathrm{~h}$ in dark and $30{ }^{\circ} \mathrm{C}$ for $8 \mathrm{~h}$ in light), according to the Brazilian Rules for Seed Testing (MAPA, 2009).

The percentage of deterioration (seed losses in the field + dead seeds found in the germination test), remaining seeds, non-dormant seeds, abnormal seedlings, viable and non-viable dormant seeds were measured in each time, using as parameter the initial number of seeds buried. After the germination test, non-germinated seeds were longitudinally cut through the embryo and kept in a $1 \%$ tetrazolium solution for imbibition in the dark for $6 \mathrm{~h}$ at $30^{\circ} \mathrm{C}$, according Brazilian Rules for Seed Testing (MAPA, 2009).

Data were subjected to the analysis of variance $(p$ $\leq 0.05)$ and the means were compared by the Tukey test $(p \leq 0.05)$ using the Statistical Analysis System software (SAS, version 9.0). Bar charts were created using the Sigmaplot software (SIGMAPLOT, version 12.3), considering interactions between time and burial depths for each variable.

\section{Results and Discussion}

For all variables measured to study persistence of Italian ryegrass in soil seed bank, significant differences were found between time and burial depths (Figure 3, 4,5 , and 6). The percentage of deteriorated seeds after burial increased over time at all depths, and higher values were observed for the seeds buried at $0.5 \mathrm{~cm}$

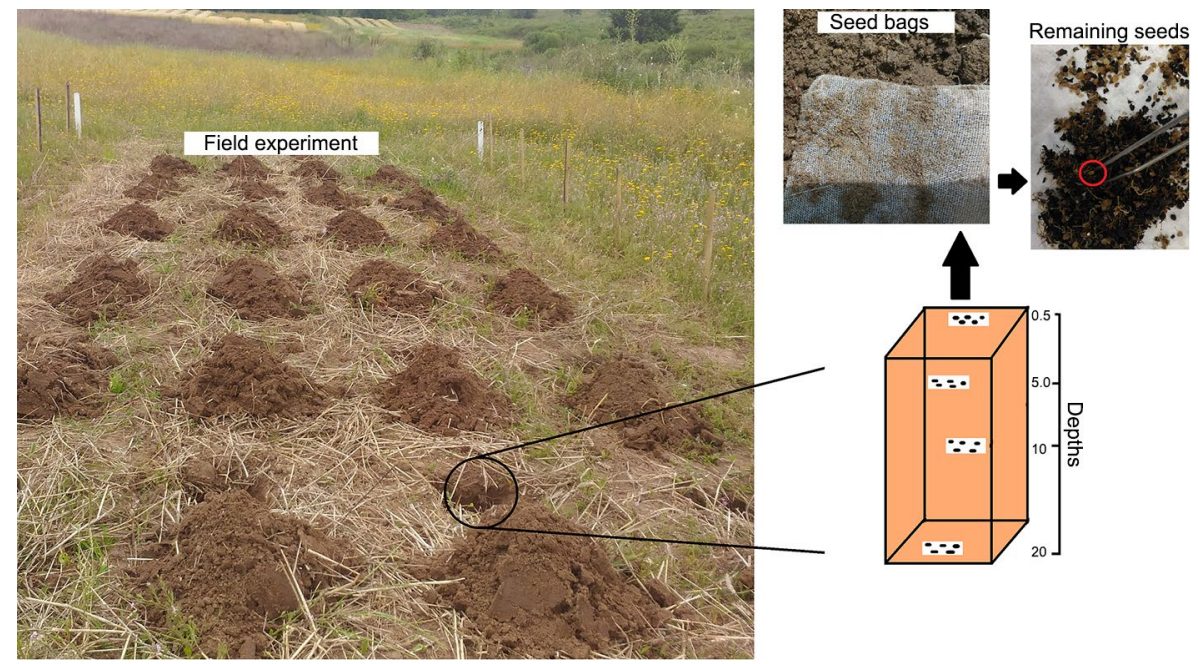

Figure 2 - Experimental layout of Italian ryegrass seed persistence, demonstrating the design plot, burial depths, seed bags, and remaining seeds over time. 
than for burial depths of 10 and $20 \mathrm{~cm}$ (Figure 3A). Similar results were reported for seed viability in Conyza bonariensis (L.) Cronq. with losses up to $59 \%$ for periods shorter than $360 \mathrm{DAB}$ (Vargas et al., 2018). At $180 \mathrm{DAB}$, burial depth of $0.5 \mathrm{~cm}$ exhibited approximately $45 \%$ of deteriorated seeds compared to $5-20 \mathrm{~cm}$ burial depths with values 35 and $28 \%$, respectively. However, more than $95 \%$ of seeds were lost up to $540 \mathrm{DAB}$, regardless of the depth evaluated (Figure 3A). Similar results were found for L. rigidum Gaudin. in which about $99 \%$ of seeds were lost after 16 months of burial, demonstrating low persistence in soil seed bank (Narwal et al., 2008).

A significant decrease of remaining seeds was found at all burial depths, especially in evaluations performed between 90 and $360 \mathrm{DAB}$, where more than 85 and $65 \%$ of seeds were lost at 0.5 and $20 \mathrm{~cm}$ depths, respectively (Figure 3B). Changes in weed dynamic in soil seed bank over time may occur due to losses by germination, migration, and degradation/predation of microorganisms and invertebrates (Chee-Sanford et al., 2006). The presence of weed seeds on surface soil layer
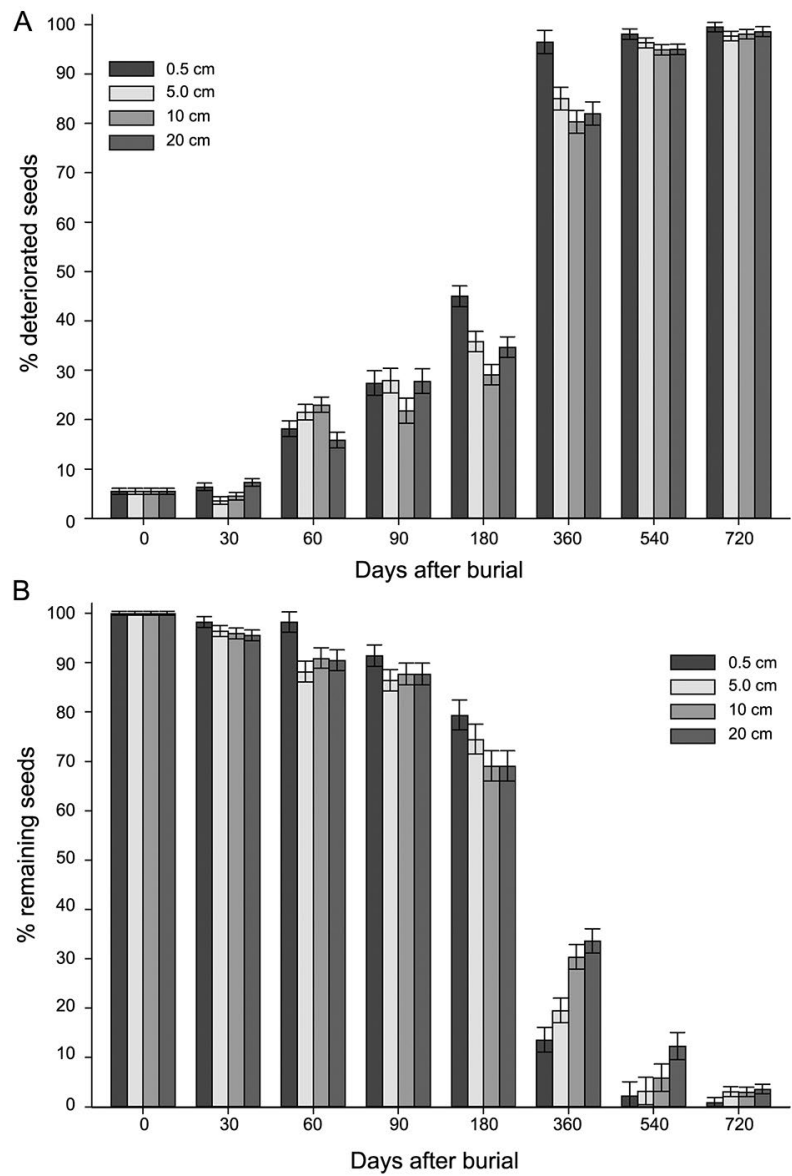

Figure 3 - Percentage of deteriorated $(A)$ and remaining seeds (B) evaluating at different times and burial depths. Error bars represent the minimum significant difference in each time by the Tukey test $(p<0.05)$. favors mortality due to frequent changes in temperature and soil moisture, factors that contribute to break seed dormancy, promoting seed germination and increasing predation and microbial activity (Main et al., 2006).

Italian ryegrass seeds buried at $20 \mathrm{~cm}$ depth showed faster dormancy breakage compared to 0.5 and $5.0 \mathrm{~cm}$, where germination of non-dormant seeds was approximately $10 \%$ higher at 30 DAB (Figure $4 \mathrm{~A})$. However, the maximum germination rate was obtained for evaluations performed between 90 and 180 DAB with more than $55 \%$ of seeds germinated due to dormancy breakage, regardless of burial depths (Figure 4A). Moreover, a decrease in the non-dormant Italian ryegrass seed number after $180 \mathrm{DAB}$ was observed as a result of increased mortality, which was demonstrated until 540 DAB when more than $95 \%$ of seeds were lost in soil bank for all depths.

In weeds, dormancy is an important evolutionary mechanism to prevent germination under unfavorable environmental conditions, contributing to the spatiotemporal adjustment, regulating the appropriate timing of seed germination under optimal conditions to ensure species development and survival (Gardarin and Colbach, 2014). Furthermore, seed dormancy breakage is regulated by several environmental and endogenous signals that may control seed physiological and biochemical processes (Née et al., 2017). Changes of temperature and soil moisture in surface layers provide faster dormancy breakage and promote mortality increase, allowing lower persistence in soil seed bank (Davis et al., 2008; Donohue et al., 2010). However, unfavorable conditions for seed germination can induce secondary dormancy to ensure germination capacity and persistence increase (Nambara et al., 2010; Graeber et al., 2012).

Percentage of abnormal seedlings at $0.5 \mathrm{~cm}$ burial depth was $2 \%$ higher than at the other depths from 60 to $90 \mathrm{DAB}$, and similar after 180 days of the experiment start (Figure 4B). Abnormal seedlings indicate seed vigor loss and reduce plant development, growth, and capacity of occupying soil seed bank, even under highly favorable environments of temperature, soil moisture, and light (Barth Neto et al., 2014). Abnormal seedlings on upper soil layers can occur due to increase of predation and microbial deterioration as well as changes of temperature and soil moisture compared to burial depths at 10 and 20 $\mathrm{cm}$ depths, which are more homogeneous environments (Née et al., 2017; Korres et al., 2018).

Considering dormant viable seeds, the field experiment started with more than $92 \%$ viable seeds evaluated by the tetrazolium test. Strong reduction in the percentage of viable dormant seeds was found until $90 \mathrm{DAB}$, with values from 5 to $17 \%$ depending on the burial depth and seed dormancy breakage in the field (Figure 5A). Similarly, the maintenance of seeds near the surface layer favored dormancy breakage and increased the percentage of non-viable dormant seeds compared to seeds buried deeper than $5 \mathrm{~cm}$ (Figure 5B). 


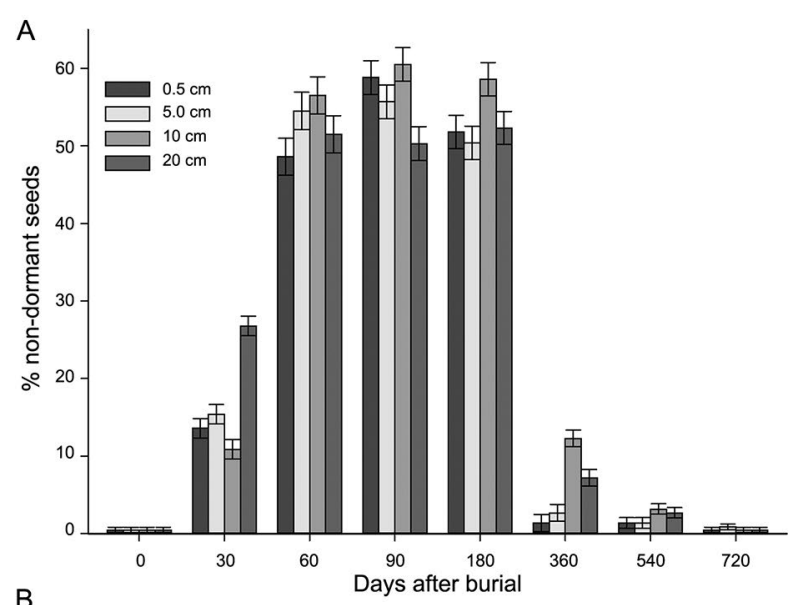

B

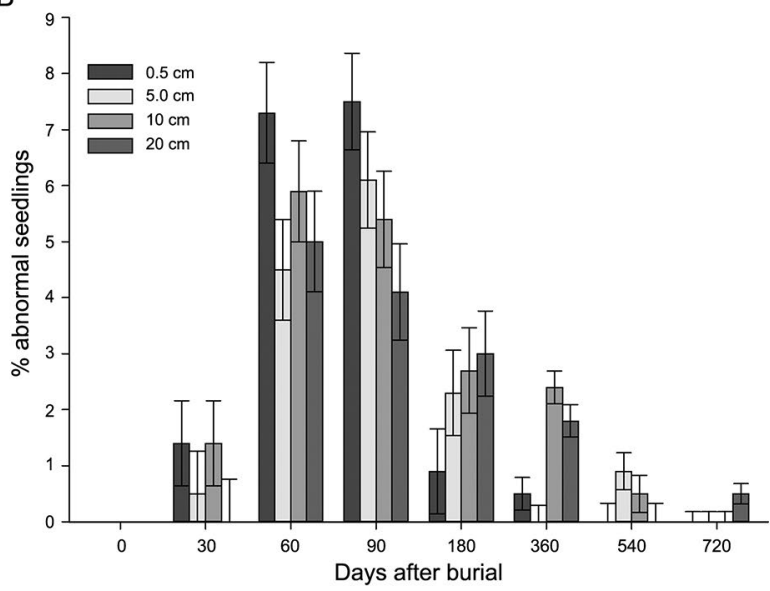

Figure 4 - Percentage of non-dormant seeds $(A)$ and abnormal seedlings (B) evaluated at different times and burial depths. Error bars represent the minimum significant difference in each time by the Tukey test $(p<0.05)$.

In agricultural systems, germination and biological processes, such as deterioration and predation of weed seeds, are stimulated by the presence of seeds on the soil surface, providing better conditions for management of soil seed bank (Goggin et al., 2012; Scherner et al., 2016; Vargas et al., 2018). Other characteristics associated the soil seed bank dynamic involve complex interactions with each kind of weed species (dormancy), environmental conditions (light, temperature, and soil moisture), biological processes, such as predation and allelopathy, and soil management practices (harrowing and/or plowing) that can affect persistence of soil seed banks (Graeber et al., 2012; Scherner et al., 2016). Moreover, crop rotation during summer and winter periods and/or the use of cover plants could be adopted by farmers to reduce the input of seeds into the soil (Galvan et al., 2015). Crop rotation is important to change herbicides used at the pre- and post-emergence of crops, whereas cover plants could reduce weed growth due to competition, reducing weed seed production.
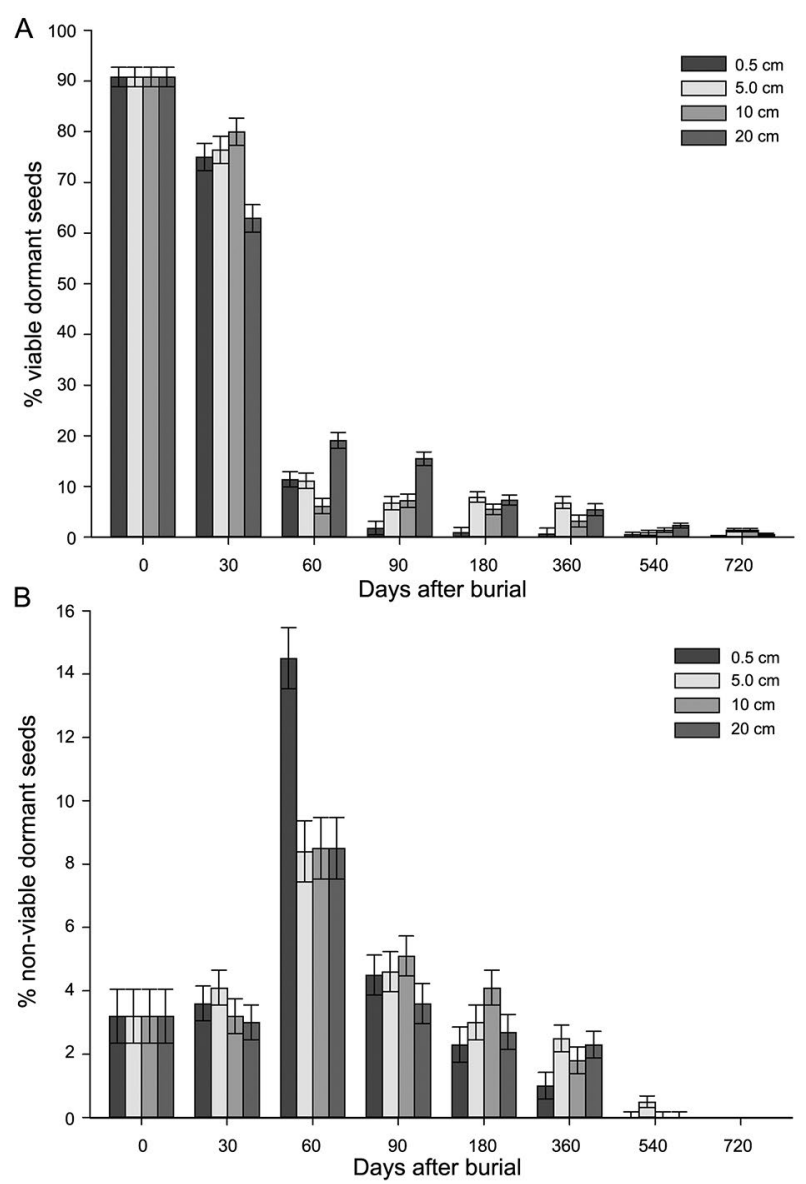

Figure 5 - Percentage of viable dormant (A) and non-viable dormant seeds (B) evaluated at different times and burial depths. Error bars represent the minimum significant difference in each time by the Tukey test $(p<0.05)$.

Our results for viable seeds, considering the sum of abnormal seedlings, non-dormant seeds, and viable dormant seeds, show that these seeds can occupy the environment and generate plants capable of completing the life cycle and producing seeds. Thus, burial at 10 and $20 \mathrm{~cm}$ depths reduced deterioration and increased persistence of Italian ryegrass seeds in soil bank (Figure 6). In addition, more than $94 \%$ of the seeds were not recovered at $540 \mathrm{DAB}$, regardless of the burial depth, indicating short persistence of Italian ryegrass in soil seed bank (Figure 6). Low viability of weed seeds was also reported in Amaranthus palmeri S. Watson (Korres et al., 2018), Conyza bonariensis (L.) Cronq. (Vargas et al., 2018) and Lolium rigidum Gaudin. (Narwal et al., 2008), which presented short persistence, depending on the burial depths.

The low viability of Italian ryegrass and maintenance of seeds on soil surface are key factors to establish more efficient management strategies and reduce soil seed bank, avoiding future infestations. Our suggestions to farmers include integrated management 

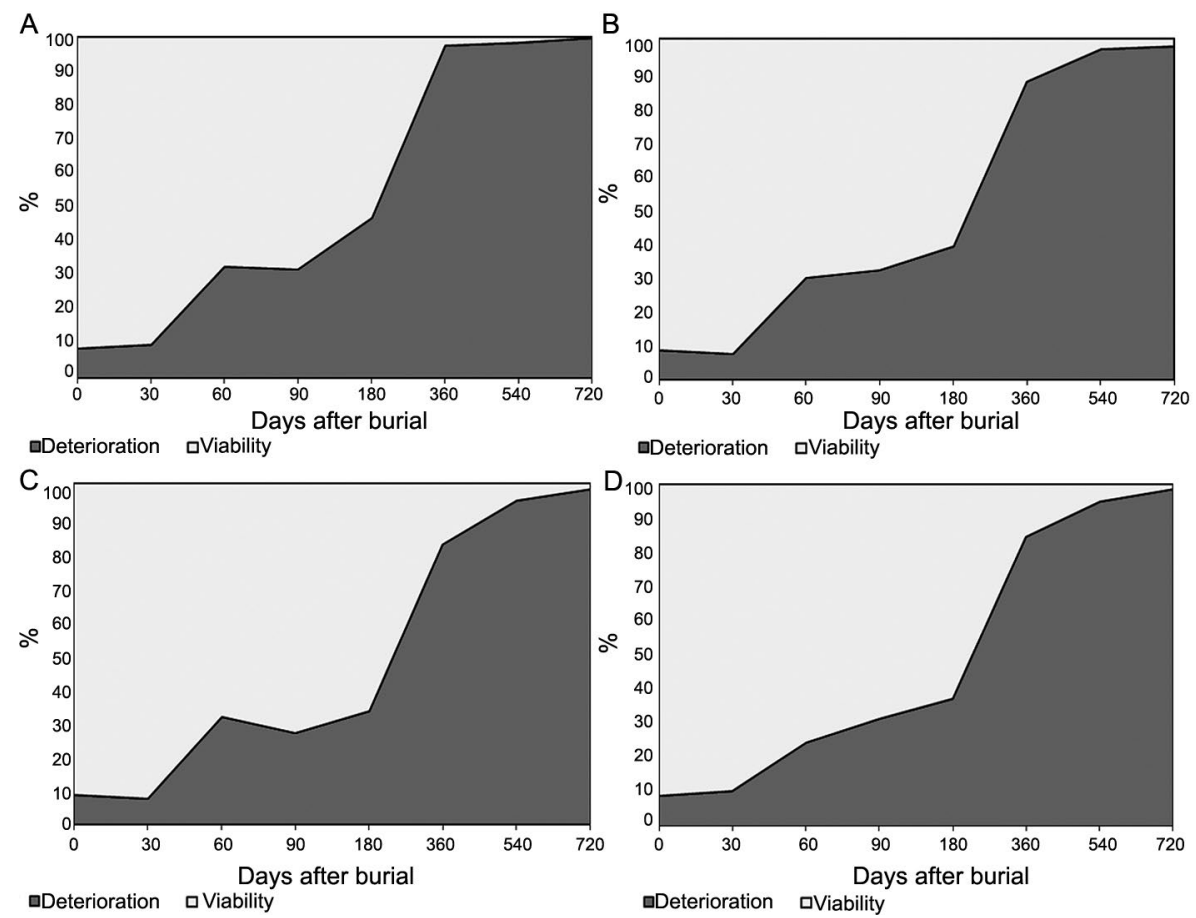

Figure 6 - Deterioration and viability of seeds buried at $0.5 \mathrm{~cm}(\mathrm{~A}), 5.0 \mathrm{~cm}(\mathrm{~B}), 10 \mathrm{~cm}(\mathrm{C})$, and $20 \mathrm{~cm}(\mathrm{D})$ depths evaluated for two years in the field experiment.

practices, such as cover crops for weed growth suppression and crop rotation, along with the chemical control to reduce infestation and seed production of Italian ryegrass.

\section{Conclusions}

Greater burial depths of Italian ryegrass seeds increase persistence in soil bank due to lower deterioration compared to seeds in the soil surface layer.

Italian ryegrass persistence in soil seed bank is short and lower than 540 days, regardless of depth.

Farmers can adopt management practices to prevent new seed inputs into the soil due to short persistence of Italian ryegrass seeds.

\section{Acknowledgements}

This study was financed in part by the Coordination for the Improvement of Higher Level Personnel - Brazil (CAPES) - Finance Code 001. Thanks also the support of Embrapa Wheat and University of Costa Rica.

\section{Authors's Contributions}

Conceptualization: Cechin, J; Agostinetto, D.; Vargas, L. Data acquisition: Cechin, J.; Schmitz, M.F.; Henckes, J.R. Data analysis: Cechin, J.; Design of Methodology: Cechin, J.; Vargas, A.A.M.; Agostinetto, D.; Vargas, L. Writing and editing: Cechin, J.

\section{References}

Armengot, L.; José-María, L.; Chamorro, L.; Sans, F.X. 2017. Avena sterilis and Lolium rigidum infestations hamper the recovery of diverse arable weed communities. Weed Research 57: 278-286.

Barth Neto, A.; Savian, J.V.; Schons, R.M.T.; Bonnet, O.J.F.; Canto, M.W.; Moraes, A.; Lemaire, G.; Carvalho, P.C.F. 2014. Italian ryegrass establishment by self-seeding in integrated croplivestock systems: effects of grazing management and crop rotation strategies. European Journal of Agronomy 53: 67-73.

Chee-Sanford, J.C.; Williams, M.M.; Davis. A.S.; Sims, G.K. 2006. Do microorganisms influence seed-bank dynamics? Weed Science 54: 575-587.

Davis, A.S.; Schutte, B.J.; Iannuzzi, J.; Renner, K.A. 2008. Chemical and physical defense of weed seeds in relation to soil seedbank persistence. Weed Science 56: 676-684.

Donohue, K.; Rubio-De-Casas, R.; Burghardt, L.; Kovach, K.; Willis, C.G. 2010. Germination, post-germination adaptation, and species ecological ranges. Annual Review of Ecology, Evolution, and Systematics 41: 293-319.

Fernández-Moreno, P.T.; Cruz, R.A.; Smeda, R.J.; De Prado, R. 2017. Differential resistance mechanisms to glyphosate result in fitness cost for Lolium perenne and L. multiflorum. Frontiers in Plant Science 8: 1-16.

Galvan, J.; Rizzardi, M.A.; Peruzzo, S.T.; Ovejero, R.F. 2015. Evolution of ryegrass seed banks depending on soil tillage and crops. Planta Daninha 33: 183-191.

Gardarin, A.; Colbach, N. 2014. How much of seed dormancy in weeds can be related to seed traits? Weed Research 55: 14-25. 
Ghersa, C.M.; Martinez-Ghersa, M.A.; Benech-Arnold, R.L. 1997. Using seed dormancy for crop and forage production. Journal of Production Agriculture 10: 111-117.

Goggin, D.E.; Powles, S.B.; Steadman, K.J. 2012. Understanding Lolium rigidum seeds: The key to managing a problem weed? Agronomy 2: 222-239.

Graeber, K.; Nakabayashi, K.; Miatton, E.; Leubner-Metzger, G.; Soppe, W.J.J. 2012. Molecular mechanisms of seed dormancy. Plant, Cell \& Environment 35: 1769-1786.

Harker, N.; O`Donovan, J.T. 2013. Recent weed control, weed management, and integrated weed management. Weed Technology 27: 1-11.

He, H.; Vidigal, D.S.; Snoek, L.B.; Schabel, S.; Nijveen, H.; Hilhorst, H.; Bentsink, L. 2014. Interaction between parental environment and genotype affects plant and seed performance in Arabidopsis. Journal of Experimental Botany 65: 6603-6615.

Jha, P.; Norsworthy, J.K.; Garcia, J. 2014. Depletion of an artificial seed bank of Palmer amaranth (Amaranthus palmeri) over four years of burial. American Journal of Plant Sciences 5: 15991606.

Korres, N.E.; Norsworthy, J.K.; Young, B.G.; Reynolds, D.B.; Johnson, W.G.; Conley, S.P.; Smeda, R.J.; Mueller, T.C.; Spaunhorst, D.J.; Gage, K.L.; Loux, M.; Kruger, G.R.; Bagavathiannan, M.V. 2018. Seedbank persistence of Palmer Amaranth (Amaranthus palmeri) and Waterhemp (Amaranthus tuberculatus) across diverse geographical regions in the United States. Weed Science 66: 446-456.

Main, C.L.; Steckel, L.E.; Hayesa, R.M.; Mueller, T.C. 2006. Biotic and abiotic factors influence horseweed emergence. Weed Science 54: 1101-1105.

Ministério da Agricultura, Pecuária e Abastecimento [MAPA]. 2009. Rules for Seed Analysis = Regras para análise de sementes. Mapa/ACS, Brasília, DF, Brazil (in Portuguese).
Nambara, E.; Okamoto, M.; Tatematsu, K.; Yano, R.; Seo, M.; Kamiya, Y. 2010. Abscisic acid and the control of seed dormancy and germination. Seed Science Research 20: 55-67.

Narwal, S.; Sindel, S.M.; Jessop, R.S. 2008. Dormancy and longevity of annual ryegrass (Lolium rigidum) as affected by soil type, depth, rainfall, and duration of burial. Plant Soil 310: 225-234.

Née, G.; Xiang, Y.; Soppe, W.J.J. 2017. The release of dormancy, a wake-up call for seeds to germinate. Current Opinion in Plant Biology 35: 8-14.

Norris, R.F. 2007. Weed fecundity: current status and future needs. Crop Protection 26: 182-188.

Scherner, A.; Melander, B.; Kudsk, P. 2016. Vertical distribution and composition of weed seeds within the plough layer after eleven years of contrasting crop rotation and tillage schemes. Soil and Tillage Research 161: 135-142.

Shaner, D.L.; Beckie, H.J. 2014. The future for weed control and technology. Pest Management Science 70: 1329-1339.

Sosnoskie, L.M.; Webster, T.M.; Culpepper, A.S. 2013. Glyphosate resistance does not affect Palmer amaranth (Amaranthus palmeri) seedbank longevity. Weed Science 61: 283-288.

Vargas, A.A.M.; Agostinetto, D.; Zandoná, R.R.; Fraga, D.S.; Avila Neto, R.C. 2018. Longevity of horseweed seed bank depending on the burial depth. Planta Daninha 36: 1-8.

Vargas, L.; Roman, E.S. 2005. Selectivity and efficacy of herbicides to winter cereals. Revista Brasileira de Herbicidas 4: 1-10 (in Portuguese, with abstract in English).

Walsh, M.J.; Harrington, R.B.; Powles, S.B. 2012. Harrington seed destructor: a new nonchemical weed control tool for global grain crops. Crop Science 52: 1343-1347. 